\title{
Helsinki alert of biodiversity and health
}

Leena von Hertzen, Bruce Beutler, John Bienenstock, Martin Blaser, Patrice D. Cani, Johan Eriksson, Martti Farkkila, Tari Haahtela, Ilkka Hanski, Maria Jenmalm, Juha Kere, Mikael Knip, Kimmo Kontula, Markku Koskenvuo, Charlotte Ling, Thomas Mandrup-Poulsen, Erika von Mutius, Mika J. Makela, Tiina Paunio, Goran Pershagen, Harald Renz, Graham Rook, Maria Saarela, Outi Vaarala, Marc Veldhoen and Willem M. de Vos

\section{Linköping University Post Print}

\section{Tweet}

N.B.: When citing this work, cite the original article.

Original Publication:

Leena von Hertzen, Bruce Beutler, John Bienenstock, Martin Blaser, Patrice D. Cani, Johan Eriksson, Martti Farkkila, Tari Haahtela, Ilkka Hanski, Maria Jenmalm, Juha Kere, Mikael Knip, Kimmo Kontula, Markku Koskenvuo, Charlotte Ling, Thomas Mandrup-Poulsen, Erika von Mutius, Mika J. Makela, Tiina Paunio, Goran Pershagen, Harald Renz, Graham Rook, Maria Saarela, Outi Vaarala, Marc Veldhoen and Willem M. de Vos, Helsinki alert of biodiversity and health, 2015, Annals of Medicine, (47), 3, 218-225.

http://dx.doi.org/10.3109/07853890.2015.1010226

Copyright: Informa Healthcare http://informahealthcare.com/

Postprint available at: Linköping University Electronic Press http://urn.kb.se/resolve?urn=urn:nbn:se:liu:diva-119806 


\section{Helsinki Alert of Biodiversity and Health}

von Hertzen L, Beutler B, Bienenstock J, Blaser M, Cani PD, Eriksson J, Färkkilä M, Haahtela T, Hanski I, Jenmalm MC, Kere J, Knip M, Kontula K, Koskenvuo M, Ling C, Mandrup-Poulsen T, von Mutius E, Mäkelä MJ, Paunio T, Peshagen G, Renz H, Rook G, Saarela M, Vaarala O, Veldhoen M, de Vos W.

Yrjo Jahnsson Foundation, Helsinki, Finland

von Hertzen L

Center for the Genetics of Host Defence, University of Texas Southwestern, Dallas, TX, USA

Beutler B

Department of Pathology, Brain-Body Institute, McMaster University Ontario, Hamilton, Canada

Bienenstock J

New York University Langone Medical Center, University of New York, New York, USA

Blaser M

Université catholique de Louvain, Louvain Drug Research Institute, WELBIO, Brussels, Belgium

Cani PD

Skin and Allergy Hospital, Helsinki University Central Hospital, Helsinki, Finland

Haahtela T, Mäkelä MJ, von Hertzen L

Department of Gastroenterology, Helsinki University Central Hospital, Helsinki, Finland

Färkkilä M

University of Helsinki, Helsinki, Finland

Department of Ecology and Evolutionary Biology

Hanski I

Department of General Practice and Primary Health Care

Eriksson J

Department of Paediatrics

Knip M

Department of Medicine

Kontula K

Department of Public Health Science

Koskenvuo M

Department of Psychiatry

Paunio T

Department of Veterinary Biosciences

de Vos W

Department of Clinical and Experimental Medicine, Linköping University, Linköping, Sweden

Jenmalm MC

Department of Biosciences and Nutrition, Karolinska Institute, Stockholm, Sweden

Kere J

Department of Clinical Sciences, Lund University, Malmö, Sweden

Ling C

University of Copenhagen

Mandrup-Poulsen T

Institute of Environmental Medicine, Karolinska Institutet, Stockholm

Pershagen $\mathrm{G}$

National Institute for Health and Welfare

Paunio T, Vaarala O

Institute of Laboratory Medicine and Pathobiochemistry, Molecular Diagnostics, Philipps University Marburg,

Germany,

Renz H

Centre for Clinical Microbiology, University College London, London, United Kingdom

Rook G

VTT Technical Research Center of Finland

Saarela M

Lymphocyte signalling and development laboratory, Babraham Institute Cambridge, Cambridge, United Kingdom Veldhoen $\mathrm{M}$ 
Department of Pediatric Allergy and Asthma at the Doctor von Hauner Children's Hospital, Ludwig Maximilian University Munich, Germany

von Mutius $\mathrm{E}$

\section{Contents}

page

1. Abstract 3

2. Introduction 4

3. The current public health challenge 5

4. The Biodiversity Hypothesis and the role of microbes
in immune tolerance

5. Factors involved in poorly developed or broken immune tolerance 6

5.1. Early and later life exposure 6

5.2. Dietary factors $\quad 7$

5.3. Home and its surrounding 8

5.4. Sedentary lifestyle 10

5.5. Antibiotics 11

6. Restoring broken tolerance 11

7. Connecting people with nature 12

8. Concluding statements 13

References 14

\section{Key words:}

biodiversity, chronic inflammatory disease, microbiota, sedentary lifestyle, Western diet 


\section{Abstract}

Urban living in built, asphalt-covered environments, combined with the use of processed water and food, may not provide the microbial stimulation necessary for a balanced development of immune function. Many chronic inflammatory disorders, including allergic, autoimmune, metabolic and even some behavioral disorders, are linked to alteration in the human commensal microbiota. Sedentary lifestyle is associated with reduced exposure to a broad spectrum of environmental microorganisms and surplus energy balance, both risk factors of chronic inflammatory disorders. According to the Biodiversity Hypothesis, an environment with diverse macrobiota and microbiota modifies and enriches the human microbiota, which in turn is crucial in the development and maintenance of appropriate immune function. These issues were discussed in the symposium "Chronic Inflammation, Lifestyle and Environment", held in Helsinki, August 2022,2014 , under the sponsorship of the Yrjö Jahnsson Foundation. This paper briefly outlines the recent findings in the context of the environment, lifestyle and health; discusses the forces that undermine immune tolerance in urban environments; and highlights the possibilities to restore broken immune tolerance among urban dwellers, summarizing the main messages in four statements and calling for actions to prevent major public health threats. 


\section{Introduction}

More than half of the world's human population lives in cities. In Europe the figure is $70 \%$, and the degree of urbanization is increasing everywhere (1). Moreover, people spend more than $90 \%$ of their lives in buildings (2), with little physical activity. Sedentary lifestyle has become a serious concern in modern societies and increases the risk of many chronic diseases. Much time spent sitting is associated with diabetes but also with other chronic diseases, including heart disease, cancer, and high blood pressure, both in adults (3) and in adolescents (4). The situation is particularly alarming among children. Parental fears ('culture of fear'), loss of natural environments in cities, increasingly busy schedules of families, and the ever-increasing time in front of the screens are some of the factors involved $(5,6)$.

Urbanization and other forms of land conversion have caused massive loss of biodiversity -affecting populations and species and their natural habitats- which is becoming a serious threat to humankind as loss of biodiversity adversely affects vital ecosystem processes related to the supply of food, water and energy as well as climate stability $(7,8)$. Less attention has been paid on the significance of natural environments on human health and well-being. However, the awareness of the formerly rather abstract concept of biodiversity loss is increasing with the accumulating data of its adverse health effects $(9,10,11)$. The epidemics of chronic inflammatory diseases (allergic and autoimmune diseases, inflammatory bowel disease and even certain cancers and depression) $(9,12-14)$ are prime examples of such effects. Exposure to natural environments enhances physical and mental health as well as cognitive functions $(8,15)$. Urban upbringing and dwelling affect neural systems that influence social stress processing in humans (16) and may lead to mental diseases, particularly anxiety and mood disorders (17).

The global concern about biodiversity loss, sedentary lifestyle and their adverse health effects was the impetus for the invitational symposium entitled "Chronic Inflammation, Lifestyle and Environment", which gathered more than 100 scientists from Europe, USA and Canada under the sponsorship of the Yrjö Jahnsson Foundation on August 20-22, 2014 in Helsinki. This 3-day Jahnsson 60 $0^{\text {th }}$ Anniversary Symposium featured presentations by 25 top speakers to promote exchange of knowledge and ideas for further research and to create public health programs concerning chronic inflammatory diseases, sedentary lifestyle and built environments. This paper briefly outlines the recent pivotal findings in the context of the environment, lifestyle and health, discusses the forces that undermine immune tolerance in urban 
environments, and highlights the possibilities to restore broken immune tolerance among urban dwellers. The main messages of the symposium are summarized in four summary statements.

\section{The current public health challenge}

Urban living in built, asphalt-covered environments with little green space, together with the use of processed water and food, may not provide us with the broad microbial stimulation necessary for the development of balanced immune function. Many chronic diseases including allergic, autoimmune, metabolic and psychiatric diseases, are linked to alteration in the commensal microbial communities (1820) and disappearance of ancient vertically and environmentally-derived species from these indigenous communities (21).

Psychiatric diseases and the gut-brain-axis have gained much attention in the past years. Consistent evidence from animal models and increasingly also from humans indicates that there is a bidirectional communication between the gut microbiota and the central nervous system (CNS) -via neural, endocrine and immune pathways- that further affects brain function and behaviour (22). For example, stress appears to influence the composition of the gut microbiota, and the microbiota in turn stress reactivity (23). Further evidence of this communication has been obtained from human studies showing that a mixture of probiotics in long-term use alleviated psychological distress and affected activity of brain regions that control emotion and sensation processing $(24,25)$. This interesting field of research has been comprehensively reviewed elsewhere (26).

Human microbiota has become a central issue in biomedicine and is expected to hold promise for the prevention and treatment of various long-term inflammatory conditions (27). Most research so far concerns the gut microbiota, but the skin and the respiratory tract microbes have increasingly been examined (28-31).

\section{The Biodiversity Hypothesis and the role of microbes in immune tolerance}

Biodiversity can be broadly defined as the variety of life on Earth. It includes the genes in all living cells, populations, species and their communities, the habitats in which they occur, and the ecosystems they comprise (Convention on Biological Diversity 1992, (http://www.biodiv.org/convention/). The Biodiversity Hypothesis proposes that reduced contact of people with natural diverse environments, including 
environmental microbiota, adversely affects the assembly and composition of human commensal microbiotas and may thereby lead to inadequate stimulation of immunoregulatory circuits and ultimately to clinical disease $(10,11)$ (Fig 1.)

The hypothesis is based on the concept that pathogen recognition receptor signaling and the regulatory network activation are needed for the normal development and maintenance of immune function and regulation. A decade ago a series of studies by Rakoff-Nahoum et al (32) provided evidence that in the intestine signaling of Toll-like receptors (TLRs) by microbial ligands is crucial for the development of tolerance and epithelial cell recovery after injury. Many other studies have corroborated these findings $(33,34)$, and immunological tolerance is, rather than an event of ignoring the invader, an active process driven by the host and microbes or bioparticles (35).

Certain members of the gut microbiota have been shown to influence development of regulatory $\mathrm{T}$ (Treg) cells and tolerance; they are able to induce Treg cell proliferation and IL-10 production by Treg or other cells. Such bacteria include Faecalibacterium prausnitzii, Bacteroides fragilis, certain Clostridium, Lactobacillus and Bifidobacteria species (36-38). In the skin microbiota, Acinetobacter Iwoffii, has been identified, among hundreds of bacteria tested (39), as a strong immunomodulator (40). The list of such immunomodulators will certainly grow in the future. The principles of TLR signaling and Treg cell functions have been reviewed comprehensively elsewhere (41-43).

\section{Factors involved in poorly developed or broken immune tolerance}

\subsection{Early and later life microbial exposure}

Compelling evidence indicates that a child's early environment, including signals transferred by the mother in prenatal life, can decisively affect the maturation of the immune system and modify the disease risk in later life $(44,45)$. Experiments on mice have revealed that maternal TLR- signaling (exposure to commensal/environmental bacteria) has a protective effect against asthma in the progeny (46). Novel findings suggest that transfer of microbes or microbial components to the child by the mother begins already in pregnancy $(47,48)$, indicating that adequate microbial stimulation, not only postnatally, but also prenatally, may be necessary for normal immune development $(20,49)$.

Environmental conditions may have effects that extend beyond several generations. The apparent heritability of cardiovascular and metabolic diseases may in fact stem from stressors experienced by (recent) ancestors early in life (50). Evidence from humans show that environmental conditions during pregnancy can change the birth characteristics and health in later life, not only of the children but also of 
the grandchildren of a mother. Experimental data from rodents and other animal models have provided further support for such epidemiological findings (reviewed in 51).

The mechanisms involved in trans-generational effects of the environmental conditions include the inheritance of epigenetic alterations. For most cell types, the epigenetic marks (e.g. DNA methylation and histone modification) become fixed as soon as the cell differentiates or exits the cell cycle (52), whereas epigenetic alteration occurring in fully differentiated adult cells are restricted only to these particular cells (51). The epigenetic programming is the product of interactions between metabolism, microbiota as well as environmental (including perinatal stressors) and dietary factors (53). Multigenerational epigenetic studies in rodents have revealed that maternal diet-related effects on body length and weight as well as glucose tolerance are transferred to subsequent generations (54). It follows that our grandparents and our parents may have provided us repercussions of diverse, microbe-rich environments and food that have provided some protection in urban environments, but this protective effect is now becoming diluted and cannot be propagated to the next generations.

Immigration studies have provided further evidence of the significance of environmental factors in early, even perinatal, life in modulating the disease risk. This immunomodulatory effect has proven to be surprisingly consistent for both chronic inflammatory and psychiatric diseases (26). Although some adaptation occurs still in adulthood (10), many studies indicate that immigrants frequently retain the disease susceptibility level typical of their country of origin. The increase in disease risk (when moving from low to high risk area) often occurs first in the 2 nd immigrant generation; important determinants in the disease risk of immigrants are thus the age at immigration and whether a person is the 1st or the 2 nd generation immigrant (26).

\subsection{Dietary factors}

Diet affects the composition of the gut microbiota and thereby maintenance of immune tolerance, but can modulate immunity via direct effects on immune cells as well $(55,56)$. Altered or poor microbiota, dysbiosis, contributes to compromised epithelial integrity and disrupted tolerance $(57,58)$. Among the dietary factors, fat consumption (high-fat diets) profoundly affects gut microbiota composition (59). The deleterious effects of fat on the immune system and gut barrier may relay on the decreased expression of specific antimicrobial peptides such as regenerating islet-derived 3-gamma (Reg3g) and phospholipase A2 group-II (PLA2g2) in the intestine. Interestingly, dietary factors such as prebiotics can abolish these effects (60). Specific bacteria e.g. Akkermansia muciniphila may also reverse high-fat diet induced metabolic disorders and reinforce intestinal immunotolerance (61). 
Comparisons of the gut microbiota of human populations living in geographically dissimilar areas have been enlightening. In addition to genetic factors, local environment and diet strongly modulate the composition of the gut microbiota $(62,63)$, although in stationary conditions, these microbial communities remain relatively stable over time $(64,65)$. The modulatory effect of diet on gut microbiota can also extend beyond generations. A recent study examined the influence of parental dietary fat consumption (Western diet and fatty acid profile) on offspring immunity in mice, finding that pups from parents on Western diet had worse outcomes in models of inflammatory diseases and heightened colonic inflammatory responses. The deleterious effects were related to alterations of the gut microbiota of the offspring (66). The concept of 'lard legacy' (54) was recently substantiated in a large epidemiological study with more than 13300 elderly men and women born in Helsinki (67).

Obesity has been associated with reduced diversity of gut microbial communities. Murine models, in which gut microbiota from fat mice has been transferred to germfree or lean mice, have provided some evidence for a causal link between microbiota and obesity (reviewed in 68), though the opposite, namely that obesity affects the composition of the gut microbiota, is also plausible. Not only caloric excess but also long-term caloric restriction may lead to changes in gut communities. Experimental studies in mice have indicated that prolonged caloric restriction increased the proportion of lactobacilli and other bacterial taxa associated with health benefits and lengthened lifespan (69). In this context, immigrant studies would be valuable for elucidating long-term consequences of dietary changes upon the gut microbiota.

In addition to caloric contents, also the composition of the diet is of key importance. Due to the activity of gut microbes, rural diets rich in fiber and starch will promote the generation of short chain fatty acids, including butyrate, a potent non-selective inhibitor of histone deacetylases (HDAC), a group of enzymes critical for the regulation of transcription and cell signaling. Indeed, low doses of HDAC inhibitors have proven benefit in animal models of inflammatory diseases and clinical trials of human inflammation (70). Butyrate is circulating in micromolar concentrations (Cani unpublished) ensuring sufficient coverage to inhibit HDAC activity in tissues. Thus, the environment is linked to diet, microbiota and inflammatory diseases via molecular mechanisms that we are only starting to understand. This understanding can form the basis of public health interventions.

\subsection{Home and its surrounding}


A number of housing and lifestyle characteristics, including the type of dwelling, affects the quantity and diversity of microbial exposure in home environments $(71,72)$. Examination of house dust has provided valuable information of the exposure to microbes in different home environments. House dust from urban environment is poor in microbial components and has biased immunomodulatory capacity as compared with dust from farm environment (73). The link between microbial richness of farm/rural dust and health has indeed been shown in a number of studies $(74,75)$. In addition to house dust, drinking water, milk, pets, unprocessed food as well as activities in nature are examples of everyday microbial exposures. Everything what we eat, drink, touch and breath is reflected in our commensal communities (Fig. 2).

Living in rural areas with agricultural and forested land is well known to confer protection against inflammatory diseases (reviewed in 76,77 ), but the protective factors at the molecular level are still only partly understood. A recent study showed that land-use around the home (within a radius of $3 \mathrm{~km}$ ) affects the composition of the skin microbiota; classes of proteobacteria were more frequent in environments with more agricultural land and forests (39). Contrasting healthy versus atopic individuals (elevated specific IgE values to inhalant allergens), the same study showed higher generic diversity of gammaproteobacteria on the skin of healthy than atopic individuals, and that the relative abundance of one gammaproteobacterial genus, Acinetobacter, correlated positively with the (unstimulated) expression of anti-inflammatory IL-10 by peripheral blood mononuclear cells (PBMC) in healthy individuals (39) and conferred protection against allergic responses in mice (40). These results provide support for low biodiversity in the environment being associated with reduced commensal microbiota, which in turn increases the risk of inflammatory condition $(78,79)$.

An illustrative study in piglets, all from the same colony, revealed that environmental exposure in early life decisively affects not only the gut microbiota in later life but also the immune transcriptome during development. Outdoor rearing was associated with the establishment of diverse microbiota and immune function, whereas indoor-housed animals showed altered gut microbiota, increased expression of proinflammatory genes, and reduced numbers of T reg cells $(80,81)$.

A series of recent population-based studies has shed light on the relationship between green environments and health. One study included 267000 randomly selected individuals in New South Wales, Australia. Percentage of green space available for recreational and physical activities within $1 \mathrm{~km}$ radius around the residence of each participant was measured. Comprehensive data on health, behavioral, socioeconomic and geographic aspects were collected using a questionnaire. After controlling for potential confounders, individuals living in greener surroundings have a significantly lower risk of diabetes and, particularly in women, of overweight and obesity, independently of physical activity and sitting time (82), in line with the 
findings of an earlier study on green environment and health (83). In addition, greener surroundings seemed to be linked to longer/better quality of sleep, and this association remained after controlling for psychological distress, physical activity and socioeconomic factors (84). People living in greener environments also walk more and are more engaged in moderate-to-vigorous physical activity (85). Nonetheless, the health benefits of green space are not explained by exercise only as shown in these and other studies $(86,87)$.

The availability of green space is an important but not the only determinant of the use of green areas. An individual's attitude (orientation) to nature and, in fact, the attitude towards nature may be an even stronger determinant for the use of green space among urban dwellers than the availability of green areas as such (88).

\subsection{Sedentary lifestyle}

Disconnection of man and nature has had consequences that are unexpected and multi-faceted. Our generation's children have been claimed to suffer from 'nature-deficit-disorder' (5), a disorder that results from inactivity and staying indoors and includes various behavioral and health problems. Urbanization and economic welfare have led to sedentary lifestyle - inactivity has become a normal state of living from the early childhood. Our lives have become increasingly dominated by technological advancements nudging us towards physical inactivity. The new innovations, while labor- and time-saving reduce the daily energy expenditure (89). A recent report from the US reveals that young people at the age of 8 to 18 years spend on average roughly 7.5 hours per day consuming some forms of electronic media (90). Sitting has become the cardinal feature in western lifestyle, and particularly work-associated sitting is a serious public health concern as it is difficult to target.

Exercise is beneficial for human health, but the scientific basis for the epidemiology of physical activity was laid only 60 years ago. Morris and coworkers showed in 1953 that bus drivers were at a substantially increased risk of cardiac events than were their physically active conductor peers (91). Physical inactivity is indeed a risk factor of the same magnitude as tobacco for poor health (92). Physical inactivity may account for $6-10 \%$ of all deaths from the major chronic diseases (coronary heart disease, type 2 diabetes, breast and colon cancer), which means 5.3 million of the 57 million premature deaths worldwide (93). At the molecular level, physical activity directly decreases the levels of inflammatory markers, CRP, TNF and in most studies also IL-6, increases Treg cell numbers and enhances the production of IL-10 and TGF $\beta(94,95)$, indicating clear anti-inflammatory properties. In asthmatic school children, physical training for 3 months 
decreased both total and allergen (mite)-specific IgE levels (96). However, physical activity still remains a largely neglected aspect of prevention and intervention of non-communicable diseases (92).

\subsection{Antibiotics}

Recent evidence from humans indicates that the use of the most common antibiotics, $\beta$-lactams and macrolides, not only disturbs the composition of the gut microbiota (by decreasing its diversity and reducing the number of core taxa (97), but can also affect many metabolic functions, including sugar metabolism and synthesis and degradation of intestinal/colonic epithelium components (98). Resilience of the gut microbiota often takes months after the cessation of the antibiotic use, although there are great variations between different antibiotics; their effect on the gut microbiota is dependent on the properties of the antimicrobial agent, and the structure, function and resistance genes of the microbial community (99). Long-term effects of these metabolic changes in the gut community still remain largely unknown.

Helicobacter pylori, an ancient member of the human gut microbiota, is an example of indigenous organisms in the human gut that were earlier common, but are now progressively disappearing. This disappearance, due to changes in the environment, lifestyle and behaviour, has been associated with the rising trends of chronic inflammatory diseases, such as asthma and allergies (21). In general, our indigenous microbiota has gradually changed and evidently we are losing many ancient, vertically and environmentally-derived species that that likely have had an important role in fine-tuning the immune responses.

\section{Restoring broken tolerance}

The adverse health effects of the disconnection of man from natural environments (100) are increasingly acknowledged. Identifying the specific factors involved is a prerequisite to strategies to restore the current situation. Sedentary lifestyle is associated with reduced exposure to environmental microbiota, together with reduced exposure to sunlight (and vitamin $D$ ), and often with surplus energy balance, all factors involved in immunity and inflammation (101). An environment with diverse macrobiota and microbiota modifies and enriches the microbiota on human skin and mucosae, which may have far-reaching consequences in conferring protection against chronic inflammation, together with dietary and other lifestyle factors. Readopting traditional dietary and lifestyle patterns, at least partly, could improve our health (101), but is difficult to attain in modern urban setting. Increasing the amounts of locally produced 
fresh fruits, berries and vegetable in our diet is beneficial, not only due to their nutritional values but also due to the high amounts of environmental friendly bacteria they carry on their surfaces (102).

As exposure to environmental microbes clearly affects the composition of the indigenous microbiota and the development of the immune system, how can a healthy balanced microbiota be obtained and maintained in urban environments? Manipulation of microbiotas, evidently very early in life, even prenatally (20), may at best provide an opportunity to change the courses of chronic inflammatory diseases (103). Alterations in commensal communities may also give clues of early stages of these diseases (104107).

\section{Connecting people with nature}

In most studies, microbiota associated with health are more diverse than those associated with various diseases (107-109). The diversity of the indigenous microbiota is linked to diversity of microbiota and macrobiota in the living environment (39), according to the biodiversity hypothesis $(10,11)$.

Adopting old-fashioned lifestyles and diets is hardly a realistic alternative in industrialized and urbanized work-oriented populations. Reconnection to nature should be built in early life to get the greatest benefits, e.g. we need more outdoor kindergartens and family/school nature clubs. We need changes in attitudes; physical activity should be a part of our daily routines. The benefits of nature in stress coping should be more acknowledged. Locally produced, unprocessed food should be preferred. The significance of what we eat, touch and breathe must be underscored. Politicians in urban planning should take into account people's need of natural environments and possibilities for physical activity in the near surroundings.

One effective tool to increase people's nature orientation and awareness of the health effects of nature contacts could be a national or local programme aiming at reconnecting people to nature and reducing their daily sitting time. For example, in Finland, both the National Asthma Programme 1994-2004 and the ongoing National Allergy Programme 2008-2018 (110, Haahtela, unpublished) have been successful. The National Health \& Nature Programme, with clearly defined goals, tools and outcome measures, targeted to both health professionals and the whole population, could be carried out in the wave of these earlier programs, based on the large experience from their implementation. New measures to reverse the increasing trends in prevalence of chronic inflammatory diseases are necessary as the old ones have been mostly ineffective. 
An interesting example of practical, grassroots action plans is the Australian initiative launched in August 2014. This 'Green Army' programme is targeted to young people, aged 17-24 years, to generate real benefits for the country, e.g. restoring and protecting habitat, weeding, planting and cleaning local environments as well as conserving cultural places. Participants, working in teams of 10 persons for 6 months, are school leavers, gap year students, graduates, unemployed job seekers and so forth, and they are paid a wage, similar to that of traineeship, by the state. The programme, in addition to improving local environments, provides young people training, skills, experience and physical activity in nature (111).

\section{Concluding statements}

Biologically diverse environments modify and enrich our indigenous microbiota, which are fundamental for the development and maintenance of a balanced/well-functioning immune system. Changes in microbiota on skin and mucosal surfaces are linked to dysfunction in the regulatory network and broken tolerance. Dysbiosis in the gut microbiota has been associated, not only with immune-mediated intestinal diseases, but also to many extra-intestinal inflammatory conditions (18).

Chronic inflammatory diseases in the context of increasing loss of biodiversity and increasing prevalence of sedentary lifestyle were the topics of the $60^{\text {th }}$ Anniversary Yrjö Jahnsson Symposium. The following summary statements emerged:

1. The epidemics of chronic inflammatory disease are largely the result of reduced exposure to natural environments, sedentary lifestyle and changed diet. Naturally biodiverse environments include ancient micro-organisms important for human health.

2. Environmental biodiversity is reflected in the diversity of human skin and mucosal microbiota. Diversity is a central element of healthy microbiota in reducing the risk of chronic inflammatory diseases.

3. A National Health \& Nature Programme (action plan) is needed to increase awareness of nature's health effects, and to affect attitudes and orientation. Especially important is to target children and adolescents; both the environment and the youngsters would benefit. 
4. Politicians and stakeholders in urban planning must become more aware about the effects of natural environments on human health. People are not moving in masses back to the countryside, but elements of country life should be moved to cities, including measures that increase the diversity of microbiota.

\section{References}

1. Dye C. Health and urban living. Science 2008;319:766-69.

2. Evans G, Mitchell J. When buildings don't work: the role of architecture in human health. J Environm Psychol 1998;18:85-94.

3. George E, Rosenkranz R, Kolt G. Chronic disease and sitting time in middle-aged Australian males: findings from the 45 and up study. Int J Behav Nutr Phys Act 2013;10:20.

4. Kriska A, Delanhanty L, Edelstein S, Amodei N, Chadwick J, Copeland K, Galvin B, El Ghormli L, Haymond M, Kelsey M, Lassiter C, Mayer-Davis E, Milaszewski K, Syme A. Sedentary behavior and physical activity in youth with recent onset of type2 diabetes. Pediatrics 2013;13:e850-6.

5. Louv R. Last Child in the Woods. London: Atlantic Books; 2009.

6. Louv R. The Nature Principle. North Carolina: Algonquin Books of Chapel Hill; 2012.

7. Hillebrand $\mathrm{H}$, Matthiessen B. Biodiversity in a complex world: consolidation and progress in functional biodiversity research. Ecol Lett 2009;12:1405-19.

8. Bratman G, Hamilton P, Daily G. The impacts of nature experience on human cognitive function and mental health. Ann NY Acad Sci 2012; 1249:118-36.

9. Rook GA. Regulation of the immune system by biodiversity from the natural environment: An ecosystem service essential to health. Proc Natl Acad Sci 2013;110:18360-7.

10. von Hertzen L, Hanski I, Haahtela T. Biodiversity loss and inflammatory diseases are two global megatrends that might be related. EMBO Reports 2011;12:1089-93.

11. Haahtela T, Holgate S, Pawankar R, Akdis C, Benjaponpital S, Caraballo L, Demain J, Portonoy J, von Hertzen L. The Biodiversity Hypothesis and allergic disease: A Statement Paper of the World Allergy Organization.

World Allergy Organ J 2013;6:3.

12. Rook GA, Raison C, Lowry C. Can we vaccinate against depression? Drug Discovery Today 2012;17:451-8.

13. Kolb H, Mandrup-Poulsen T. The global diabetes epidemic as a consequence of life-style induced low-grade inflammation. Diabetologia 2010;53:10-20.

14. Jussila A, Virta LJ, Salomaa V, Mäki J, Jula A, Färkkilä MA. High and increasing prevalence of inflammatory bowel disease in Finland with a clear North-South difference. J Crohns Colitis 2013;7:e256-62.

15. Karjalainen E, Sarjala T, Raitio H. Promoting human health through forests: overview and major challenges. Environ Health Prev Med 2010;15:1-8. 
16. Lederbogen F, Kirsch P, Hahhad L, Streit F, Tost H, Schuch P, Wüst S, Pruessner JC, Rietschel M, Deuschle M, Meyer-Linderberg A. City living and urban upbringing affect neural social stress processing in humans. Nature 2011;474:498-501.

17. Peen J, Schoevers R, Beekman A, Dekker J. The current status of urban-rural differences in psychiatric disorders. Acta Psychiatr Scand 2010;121:84-93.

18. Ray K. Married to our gut microbiota. Nat Rev Gastroenterol Hepatol 2012;9:555.

19. Bienenstock J, Collins S. Psychoneuroimmunology and the intestinal microbiota: clinical observations and basic mechanisms. Clin Exp Immunol 2010;160:85-91.

20. West C, Jenmalm M, Prescott S. The gut microbiota and its role in the development of allergic disease: a wider perspective. Clin Exp Allergy 2014, epub ahead of print.

21. Blaser M, Falkow S. What are the consequences of the disappearing human microbiota? Nat Rev Microbiol 2009;7:887-94.

22. Cryan JF, Dinan TG. Mind-altering microorganisms: the impact of the gut microbiota on brain and behavior. Nat Rev Neurosci 2012;13:701-12.

23. Foster JA, McVey Neufeld KA. Gut-brain axis: how the microbiome influences anxiety and depression. Trends in Neurosci 2013;36:305-12.

24. Messaoudi M, Lalonde R, Violle N, Javelot H, Desor D, Nejdi A. Bisson JF, Rougeot C, Pichelin M, Cazaubiel M, Cazaubiel JM: Assessment of psychotropic-like properties of a probiotic formulation (Lactobacillus helveticus R0052 and Bifidobacterium longum R0175) in rats and human subjects. Br J Nutr 2011;105:755-64.

25. Tillisch K, Labus J, Kilpatrick L, Jiang Z, Stains J, Ebrat B, Guyonnet D, Legrain-Raspaud S, Trotin B, Naliboff B, Mayer EA. Consumption of fermented milk product with probiotic modulates brain activity. Gastroenterology 2013;144:1394-401.

26. Rook GAW, Raison CL, Lowry CA. Microbial "Old Friends", immunoregulation and psychiatric disorders. In: Heidt PJ, Bienenstock J, Rusch V, editors. The gut mictobiome and the nervous system. Herborn: Old Herborn University; 2013. p. 61-90. Available at: http://www.old-herborn-university.de/literature/books/OHUni book 26 article 6.pdf

27. Shanahan F. The gut microbiota - a clinical perspective on lessons learned. Nat Rev Gastroenterol Hepatol 2012;9:609-14.

28. Gao Z, Tseng C, Pei Z, Blaser M. Molecular analysis of human forearm superficial skin bacterial biota. Proc Natl Acad Sci 2007;104:2927-32.

29. Grice E, Kong H, Conlan S, Deming C, Davis J, Young A, NISC Comparative Sequencing Program, Bouffard G, Blakesley R, Murray P, Green E, Turner M, Segre J. Topographical and temporal diversity of the human skin microbiome. Science 2009;324:1190-2.

30. Huang Y, Charlson E, Collman R, Colombini-Hatch S, Martinez F, Senior R. The role of lung microbiome in health and disease. A National Heart, Lung and Blood Institute Workshop Report. Am J Respir Crit Care Med 2013;187:13827.

31. Gollwitzer ES, Saglani S, Trompette A, Yadava K, Sherburn R, McCoy K, Nicod LP, Lloyd C, Marsland B. Lung microbiota promotes tolerance in neonates via PD-L1. Nature Med 2014;20:642-7.

32. Rakoff-Nahoum S, Paglino J, Eslami-Varzaneh F, Edberg S, Medzhitov R. Recognition of commensal microflora by Toll-like receptors is required for intestinal homeostasis. Cell 2004;118:229-41. 
33. Abreu MT. Toll-like receptor signaling in the intestinal epithelium: how bacterial recognition shapes intestinal function. Nat Rev Immunol 2010;10:131-44.

34. Kubinak J, Round J. Toll-like receptors promote mutually beneficial commensal-host interactions. PLoS Pathogens 2012;8:e1002785

35. Joenväärä S, Mattila P, Renkonen J, Mäkitie A, Toppila-Salmi S, Lehtonen M, et al. Caveolar traffic through nasal epithelium of birch pollen allergen Bet v 1 in allergic patients. J Allergy Clin Immunol 2009;124:135-142.

36. Round JL, O'Connell RM, Mazmanian SK. Coordination of tolerogenic immune responses by the commensal microbiota. J Autoimmun 2010;34:J220-25.

37. Sagar S, Morgan ME, Chen S, Vos AP, Garssen J, Bergenhenegouwen J, Boon L, Georgiou NA, Kraneveld AD, Folkerts $\mathrm{G}$. Bifidobactreium breve and Lactobacillus rhamnosis treatment is as effective as budesonide at reducing inflammation in a murine model for chronic asthma. Respir Res 2014;15:46.

38. Atarashi K, Honda K. Microbiota in autoimmunity and tolerance. Curr Opin Immunol 2011;23:761-68.

39. Hanski I, von Hertzen L, Fyhrquist N, Koskinen K, Torppa K, Laatikainen T, Karisola P, Auvinen P, Paulin L, Mäkelä MJ, Vartiainen E, Kosunen TU, Alenius H, Haahtela T. Environmental biodiversity, human microbiota, and allergy are interrelated. Proc Natl Acad Sci 2012;109:8334-9.

40. Fyhrquist $N$, Ruokolainen L, Suomalainen A, Lehtimäki S, Veckman V, Vendelin J, Karisola P, Lehto M, Savinko T, Jarva H, Kosunen T, Corander J, Auvinen P, von Hertzen L, Laatikainen T, Mäkelä M, Haahtela TY, Greco D, Hanski I, Alenius $\mathrm{H}$. Acinetobacter in the skin microbiota protects from allergic sensitization and inflammation. J Allergy Clin Immunol (in press)

41. Beutler B. TLRs and innate immunity. Blood 2009;113:1399-1407.

42. Sakaguchi S, Miyara M, Costantino C, Hafler D. Foxp3+ regulatory T cells in the human immune system. Nat Rev Immunol 2010;10:490-500.

43. Vignali D, Collison L, Workman C. How regulatory T cells work. Nat Rev Immunol 2008;8:523-32.

44. Pfefferle PI, Pinkenburg O, Renz H. Fetal epigenetic mechanisms and innate immunity in asthma. Curr Allergy Asthma Rep 2010;10:434-43.

45. Barouki R, Gluckman P, Granfjean P, Hanson M, Heindel J. Developmental origins of non-communicable disease: implications for research and public health. Environ Health 2012;11:42.

46. Conrad M, Ferstl R, Teich R, Brand S, Blümer N, Yildirim A, Patrascan C, Hanuszkiewicz A, Akira S, Wagner H, Holst $\mathrm{O}$, von Mutius E, Pfefferle P, Kirschning C, Garn H, Renz H. Maternal TLR signaling is required for prenatal asthma protection by the nonpathogenic microbe Acinetoacter Iwoffii F78. J Exp Med 2009;206: 2869-77.

47. Aagaard K, Ma J, Antony KM, Ganu R, Petrosino J, Versalovic J. The placenta harbors a unique microbiome. Sci Transl Med 2014;6:237

48. Funkhouser LJ, Bordenstein SR. Mom knows best: the universality of maternal microbial transmission. PLoS Biol 2013;11:e1001631.

49. Rautava S, Luoto R, Salminen S, Isolauri E. Microbial contact during pregnancy, intestinal colonization and human disease. Nat Rev Gastroenterol Hepatol 2012;9:565-76.

50. Patti ME. Intergenerational programming of metabolic disease: evidence from human population and experimental animal models. Cell Mol Life Sci 2013;70:1597-1608. 
51. Burton T, Metcalfe N. Can environmental conditions experienced in early life influence future generations? Proc $R$ Soc 2014;281:20140311.

52. Morgan H, Santos F, Green K, Dean W, Reik W. Epigenetic reprogramming in mammals. Hum Mol Genet 2005;14:R47-R58.

53. Shenderov B Midtvedt T. Epigenomic programing: a future way to health? Microb Ecol Health Dis 2014;25:24145.

54. Parlee S, MacDougald O. Maternal nutrition and risk of obesity in offspring: the Troijan horse of developmental plasticity. Biochim Biophys Acta 2014;1842:495-506.

55. Thorburn AN, Macia L, Mackay CR. Diet, metabolites, and 'western-lifestyle' inflammatory diseases. Immunity $2014 ;$ 40:833-42.

56. Veldhoen M, Brucklacher-Waldert V. Dietary influences on intestinal immunity. Nat Rev Immunol 2012;12:696708.

57. Moens E, Veldhoen M. Epithelial barrier biology: good fences make good neighbours. Immunology 2011;135:1-8.

58. Macia L, Thorburn A, Binge L, Marino E, Rogers K, Maslowski K, Vieira A, Kranich J, Mackey C. Microbial influences on epithelial integrity and immune function as a basis for inflammatory diseases. Immunol Rev 2012;245:164-76.

59. Cani PD1, Amar J, Iglesias MA, Poggi M, Knauf C, Bastelica D, Neyrinck AM, Fava F, Tuohy KM, Chabo C, Waget A, Delmée E, Cousin B, Sulpice T, Chamontin B, Ferrières J, Tanti JF, Gibson GR, Casteilla L, Delzenne NM, Alessi MC, Burcelin R. Metabolic endotoxemia initiates obesity and insulin resistance. Diabetes 2007;56:1761-72.

60. Everard A, Lazarevic V, Gaïa N, Johansson M, Ståhlman M, Backhed F, Delzenne NM, Schrenzel J, François P, Cani PD. Microbiome of prebiotic-treated mice reveals novel targets involved in host response during obesity. ISME J 2014; 8:2116-30.

61. Everard A, Belzer C, Geurts L, Ouwerkerk JP, Druart C, Bindels LB, Guiot Y, Derrien M, Muccioli GG, Delzenne NM, de Vos WM, Cani PD. Cross-talk between Akkermansia muciniphila and intestinal epithelium controls diet-induced obesity. Proc Natl Acad Sci 2013;110:9066-71.

62. De Filippo C, Cavalieri D, Di Paola M, Ramazzotti M, Poullet JB, Massart S, Collini S, Pieraccini G, Lionetti P. Impact of diet in shaping gut microbiota revealed by a copmparative study in children from Europe and rural Africa. Proc Natl Acad Sci 2010;107:14691-6.

63. Yatsunenko T, Rey F, Manary M, Trehan I, Dominigueq-Bello M, Contreras M, Magris M, Hidalgo G, Baldassano R, Anokhin A, Heath A, Warner B, Reeder J, Kuczynski J, Caporaso G, Lozupone C, Lauber C, Clemente JC, Knights D, Knight R, Gordon J. Human gut microbiome viewed across age and geography. Nature 2012;486:222-9.

64. Kolmeder C, de Been M, Nikkilä J, Ritamo I, Mättö J, Valmu L, Salojärvi J, Palva A, Salonen A, de Vos W. Comparative metaproteomics and diversity analysis of human intestinal microbiota testifies for its temporal stability and expression of core functions. PLoS One 2012;7:e29913.

65. Faith JJ, Guruge JL, Charbonneau M, Subramanian S, Seedorf H, Goodman AL, Clemente JC, Knight R, Heath AC, Leibel RL, Rosenbaum M, Gordon Jl. The long-term stability of the human gut microbiota. Science 2013;341:1237439

66. Myles I, Fontecilla N, Janelsins B, Vithayathil P, Serge J, Datta S. Parental dietary fat intake alters offspring microbiome and immunity. J Immunol 2013;191:3200-9.

67. Eriksson JG, Sandboge S, Salonen MK, Kajantie E, Osmond C. Long-term consequences of maternal overweight in pregnancy on offspring later health: Findings from the Helsinki Birth Cohort Study. Ann Med 2014;46:434-38. 
68. Kau A, Ahern P, Griffin N, Goodman A, Gordon J. Human nutrition, the gut microbiome and the immune system. Nature 2011;474:327-36.

69. Zhang C, Li S, Yang L, Huang P, Li W, Wang S, Zhao G, Zhang M, Pang X, Yan Z, Liu Y, Zhao L. Structural modulation of gut microbiota in life-long calorie-restricted mice. Nat Commun 2013;4:2163.

70. Christensen DP, Dahllöf M, Lundh M, Rasmussen DN, Nielsen MD, Billestrup N, Grunnet LG, Mandrup-Poulsen T. Histone deacetylase (HDAC) inhibition as a novel treatment for diabetes mellitus. Mol Med 2011;17:378-90.

71. Leppänen H, Täubel M, Roponen M, Vepsäläinen A, Rantakokko P, Pekkanen J, Nevalainen A, von Mutius E, Hyvärinen A. Determinants, reproducibility and seasonal variation of bacterial cell wall components and viable counts in house dust. Indoor Air 2014, epub ahead of print.

72. Lax S, Smith DP, Hampton-Marcell J, Owens SM, Handley KM, Scott NM, Gibbons SM, Larsen P, Shogan BD, Weiss S, Metcalf JL, Ursell LK, Vázquez-Baeza Y, Van Treuren W, Hasan NA, Gibson MK, Colwell R, Dantas G, Knight R, Gilbert $\mathrm{JA}$. Longitudinal analysis of microbial interaction between humans and the indoor environment. Science 2014;345:1048-52.

73. Alenius H, Pakarinen J, Saris O, Andersson MA, Leino M, Sirola K, Majuri ML, Niemelä J, Matikainen S, Wolff H, von Hertzen L, Mäkelä M, Haahtela T, Salkinoja-Salonen M. Contrasting immunological effects of two disparate dusts preliminary observations. Int Arch Allergy Immunol 2008;149:81-90.

74. Ege MJ, Mayer M, Normand AC, Genuneit J, Cookson W, Braun-Fahrländer C, Heederik D, Piarroux R, von Mutius E; GABRIELA Transregio 22 Study Group. N Engl J Med 2011;364:701-9.

75. Heederik D, von Mutius E. Does diversity of environmental microbial exposure matter for the occurrence of allergy and asthma? J Allergy Clin Immunol 2012;130:44-50.

76. von Mutius E, Vercelli D. Farm living: effects on childhood asthma and allergy. Nat Rev Immunol 2010;10:861-6.

77. Wlasiuk G, Vercelli D. The farm effect, or: when, what and how a farming environment protects from asthma and allergic disease. Curr Opin Allergy Clin Immunol 2012;12:461-6.

78. Lynch SV, Wood RA, Boushey H, Bacharier LB, Bloomberg GR, Kattan M, O'Connor GT, Sandel MT, Calatroni A, Matsui E, Johnson CC, Lynn H, Visness CM, Jaffee KF, Gergen PJ, Gold DR, Wright RJ, Fujimura K, Rauch M, Busse WW, Gern JE. Effects of early-life exposure to allergens and bacteria on recurrent wheeze and atopy in urban children. J Allergy Clin Immunol 2014;134:593-601.

79. Fujimura KE, Demoor T, Rauch M, Faruqi AA, Jang S, Johnson CC, Boushey HA, Zoratti E, Ownby D, Lucas NW, Lynch SV. House dust exposure mediates gut microbiome Lactobacillus enrichment and airway immune defense against allergens and virus infection. Proc Natl Acad Sci 2014;111:805-10

80. Mulder I, Schmidt B, Stokes C, Lewis M, Bailey M, Aminov R, Prosser J, Gill B, Pluske J, Mayer CD, Musk C, Kelly D. Environmentally-acquired bacteria influence microbial diversity and natural innate immune responses at gut surfaces. BMC Biology 2009;7:79.

81.Lewis MC, Inman CF, Patel D, Schmidt B, Mulder I, Miller B, Gill BP, Pluske J, Kelly D, Stokes CR, Bailey M. Direct experimental evidence that early-life farm environment influences regulation of immune responses. Pediatr Allergy Immunol 2012;23:265-9. 
82. Astell-Burt T, Feng X, Kolt GS. Is neighborhood green space associated with a lower risk of type 2 diabetes? Evidence from 267072 Australians. Diabetes Care 2014;37:197-201.

83. Mitchell R, Popham F. Effect of exposure to natural environment on health inequalities: an observational population study. Lancet. 2008;372:1655-60.

84. Astell-Burt T, Feng X, Kolt GS. Does access to neighborhood green space promote a healthy duration of sleep? Novel findings from cross-sectional study of 259319 Australians. BMJ Open 2013;3:e003094.

85. Astell-Burt T, Feng X, Kolt GS. Greener neighborhoods, slimmer people? Evidence from 246920 Australians. Int J Obes 2014;38:156-9.

86. Maas J, Verheij RA, Spreeuwenberg P, Groenewegen PP. Physical activity as a possible mechanism behind the relationship between green space and health: a multilevel analysis. BMC Public Health 2008;8:206.

87. Lachowycz K, Jones AP. Does walking explain associations between access to greenspace and lower mortality? Soc Sci Med 2014;107:9-17.

88. Lin B, Fuller R, Bush R. Gaston K, Shanahan D. Opportunity or orientation? Who uses urban parks and why? PLoS One 2014;9:e87422.

89. Hallal P, Bauman A. Heath G, Kohl H, Lee IM, Pratt M. Physical activity: more of the same is not enough. Lancet 2012;380:190-1.

90. Generation $\mathrm{M}^{2}$. Media in the lives of 8 to 18 -year-olds. A Kaiser Family Foundation Study. 2010. Available at: http://www.kff.org

91. Morris J, Heady J, Raffle P, Roberts C, Parks J. Coronary heart-disease and physical activity of work. Lancet 1953;262:1111-20.

92. Das P, Horton R. Rethinking our approach to physical activity. Lancet 2012;380:189-90.

93. Lee MI, Shiroma E, Lobelo F, Puska P, Blair S, Katzmarzyk P. Effect od physical inativity on major noncommunicable diseases worldwide: an analysis of burden of disease and life expectancy. Lancet 2012;380:219-29.

94. Bruunsgaard H. Physical activity and modulation of systemic low-level inflammation. J Leukoc Biol 2005;78:819-35.

95. Yeh SH, Chuang H, Lin LW, Hsiao CY, Eng HL. Regular tai chi chuan exercise enhances functional mobility and CD4CD25 regulatory T cells. Br J Sports Med 2006;40:239-43.

96. Moreira A, Delgado L, Haahtela T, Fonseca J, Moreira P, Lopes C, Monta J, Santos P, Rytilä P, Castel-Branco MG. Physical training does not increase allergic inflammation in asthmatic children. Eur Respir J 2008;32:1570-75.

97. Panda S, El khader I, Casellas F, Lopez Vivancos J, Garcia Cors M, Santiago A, Cuenca S, Guarner F, Manichanh C. Short-term effects of antibiotics on human gut microbiota. PLoS One 2014;9:e95476.

98. Ferrer M, Martins dos Santos VA, Ott SJ, Moya A. Gut microbiota disturbance during antibiotic therapy: a multiomic approach. Gut Microbes 2014;5:64-70

99. Perez-Cobas AE, Artacho A, Knecht H, Ferrus ML, Friedrichs A, Ott SJ, Moya A, Latorre A, Gosalbes MS. Differential effects of antibiotic therapy on the structure and function of human gut microbiota. PLoS One 2013;8:e80201.

100. Hertzen L, Haahtela T. Disconnection of man and the soil -reason for the asthma and atopy epidemic? J Allergy Clin Immunol 2006;117:334-44. 
101. Prescott SL. Early-life environmental determinants of allergic diseases and the wider pandemic of inflammatory noncommunicable diseases. J Allergy Clin Immunol 2013;131:23-30.

102. Jawetz E, Melnick J, Adelberg E. Review of Medical Microbiology.Los Altos, CA: Lange Medical Publications;1980, p. 99-100.

103. Martinez FD. The human microbiome. Early life determinant of health outcomes. Ann Am Thorac Soc 2014;11 (suppl 1):S7-S12.

104. de Vos W, Nieuwdorp M. Genomics: A gut prediction. Nature 2013;498:48-9.

105. Vaarala O. In the origin of type 1 diabetes in the gut? Immunol Cell Biol 2012;90:271-6.

106. Abrahamsson TR, Jakobsson HE, Andersson AF, Björksten B, Engstrand L, Jenmalm MC. Low gut microbiota diversity in early infancy precedes asthma at school age. Clin Exp Allergy. 2014;44:842-50.

107. Abrahamsson $T$, Jakobsson $H$, Andersson A, Björksten B, Engstrand L, Jenmalm M. Low diversity of the gut microbiota in infants with atopic eczema. J Allergy Clin Immunol 2012;129:434-40.

108. Garn H, Neves J, Blumberg R, Renz H. Effect of barrier microbes on organ-based inflammation. J Allergy Clin Immunol 2013;131:1465-78.

109. Pfefferle PI, Prescott S, Kopp M Microbial influence on tolerance and opportunities for intervention with prebiotics/probiotics and bacterial lysates. J Allergy Clin Immunol 2013;131:1453-63.

110. Haahtela T, Tuomisto LE, Pietinalho A, Klaukka T, Erhola M, Kaila M, Nieminen MM, Kontula E, Laitinen LA. A 10 year asthma programme in Finland: major change for the better. Thorax 2006;61:663-70.

111. www.environment.gov.au/land/green-army

112. Haahtela T. What is needed for allergic children? Pediatr Allergy Immunol 2014;25:21-4. 


\section{Legends for figures}

Figure 1.

Biodiversity loss, together with sedentary lifestyle and unhealthy diet, may lead to immune dysregulation, poor tolerance and ultimately to clinical disease. Modified from (112).

\section{Figure 2.}

'We are what we host, and we host what we eat, touch and breathe'. Outdoor activities in biodiverse environments together with unprocessed food can provide us microbial exposure necessary for the development and maintenance of healthy balanced microbiota and immunoregulatory circuits. 
Biodiversity and health

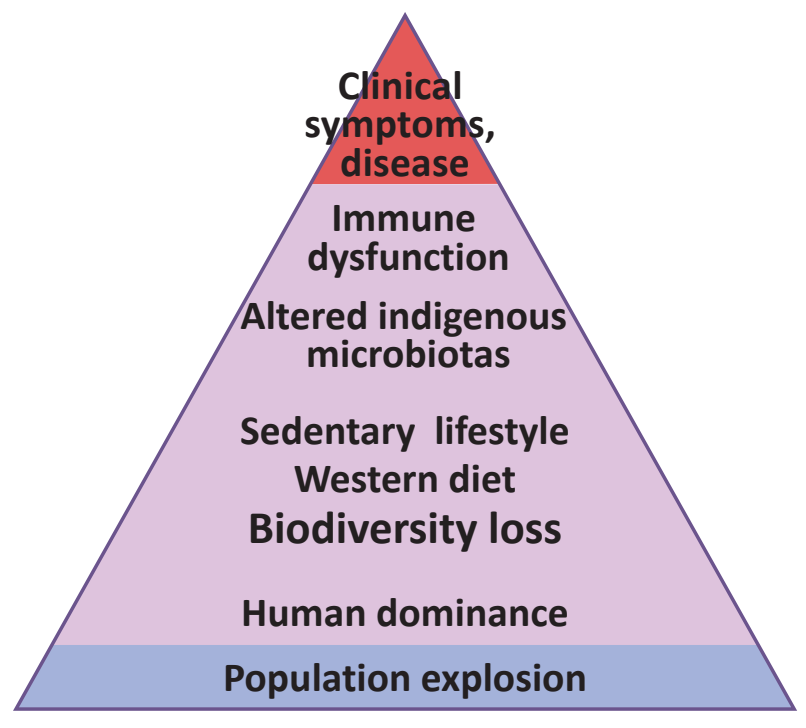


Acquisition/maintenance of healthy indigenous microbiotas

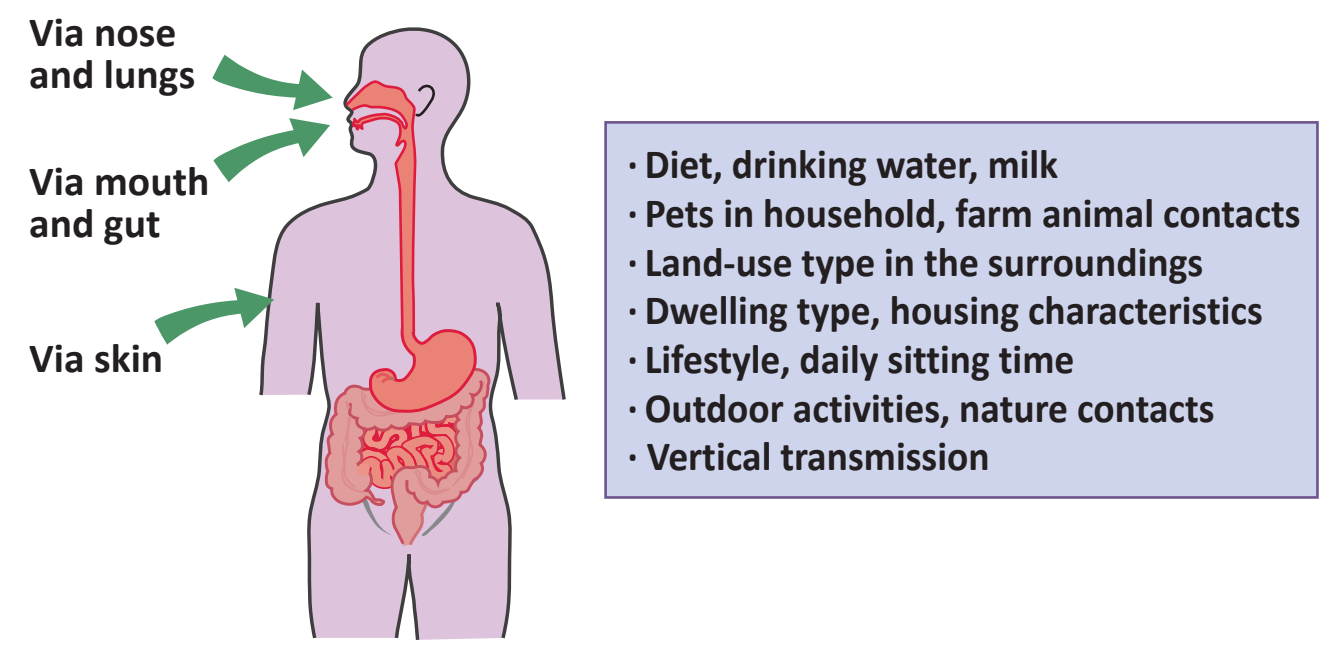

